\title{
Natural history of extensive diaphragmatic injury on the right side: experimental study in rats
}

\author{
História natural do ferimento diafragmático extenso à direita: estudo \\ experimental em ratos
}

Jorge Henrique Rivaben, ACBC-SP1; Roberto SaAd Junior, TCBC-SP1; Vicente Dorgan Neto, TCBC-SP1; Marcio Botter, TCBCSP'; ROBERTO GONÇALVES, TCBC-SP'1

\section{A}

\begin{abstract}
Objective: To evaluate the natural healing of the rat diaphragm that suffered an extensive right penetrating injury. Methods: Animals were submitted to an extensive penetrating injury in right diaphragm. The sample consisted of 40 animals. The variables studied were initial weight, weight 21 days after surgery; healing of the diaphragm, non-healing of the diaphragm, and herniated abdominal contents into the chest. Results: Ten animals were used as controls for weight and 30 animals were operated. Two animals died during the experiment, so 28 animals formed the operated group; healing of the diaphragm occurred in 15 animals (54\%), 11 other animals showed diaphragmatic hernia (39\%) and in two we observed only diaphragmatic injury without hernia (7\%). Among the herniated organs, the liver was found in 100\% of animals, followed by the omentum in $77 \%$, small bowel in $62 \%$, colon in $46 \%$, stomach in $31 \%$ and spleen in 15\%. The control group and the diaphragmatic healing subgroup showed increased weight since the beginning of the study and the 21 days after surgery $(p<0.001)$. The unhealed group showed no change in weight $(p=0.228)$. Conclusion: there is a predominance of spontaneous healing in the right diaphragm; animals in which there was no healing of the diaphragm did not gain weight, and the liver was the organ present in $100 \%$ the diaphragmatic surface in all rats with healed diaphragm or not.
\end{abstract}

Key words: Diaphragm. Wound Healing. Diaphragm/injuries. Animal Experimentation.

\section{INTRODUCTION}

\begin{abstract}
A ccording to the current concept, the diaphragmatic muscle injured by a penetrating or blunt injury will not heal. The accepted theory describes that there is a difference between the negative intrathoracic pressure and the positive one in the abdominal cavity, preventing the coaptation of the injured margins. The very restless nature of muscle, constantly contracting and relaxing in the breathing process, would also prevent spontaneous healing. Indeed, one of the principles of wound healing is to keep the wound edges (whatever the tissue) joined and at rest. Therefore it is logical to assume that spontaneous diaphragm healing does not occur ${ }^{\text {. }}$.

On the other hand, from the pioneer experimental study in rats conducted in 2001 and published in 2007, which showed the possibility of healing of the diaphragm, either on the right or on the left, of injuries which jeopardized $5 \%$ of diaphragm surface, we launched a line of research with a number of experimental projects to understand how a diaphragmatic wound evolves. It was surprising that in this pioneering work spontaneous healing occurred in 100\% on the right side and in $86 \%$ on the left side 2 .
\end{abstract}

Therefore, since 2001 we have been developing experimental works in the Department of Surgery of the Santa Casa de São Paulo, to clarify this phenomenon, ie, to define the natural history of a diaphragmatic injury. The pioneering study showed us very clearly that small lesions, of up to $5 \%$ of the diaphragmatic surface, heal, so we designed similar studies, but with larger lesions, to determine whether healing also happens in these cases.

Our aim was to macroscopically evaluate the natural healing of the right diaphragm of rats after a 30\% perforating injury.

\section{METHODS}

The study was carried out at the Unit of Experimental Surgical Technique (UTECE), Department of Surgery, Faculdade de Ciências Médicas da Santa Casa de São Paulo (FCMSC), and was approved by the Ethics Committee on Animal Experimentation of FCMSC-SP, under Protocol 114 12005.

We used Rattus norvegiccus allbinus that were received with about 90 days of age and kept for ambiance

1. Department of Surgery, Faculty of Medical Sciences, Santa Casa da Misericórdia, São Paulo. 
in collective cages for ten days, with a population density of five animals per cage, with free access to water and proper food. We set a light-dark cycle of 12 hours (light on from 7 to 19 hours). The cages were routinely cleaned and lined with autoclaved wood shavings.

After setting, the animals were fasted for ten hours before the procedure. All rats were anesthetized by intraperitoneal application of ketamine at a dose of $50 \mathrm{mg}$ $/ \mathrm{kg}$ and xilazine hydrochloride at a dose of $5 \mathrm{mg} / \mathrm{kg}$. The animals were then positioned in supine on the operative plank with fixed legs. Then we performed trichotomy and measures of asepsis and antisepsis with $10 \%$ povidoneiodine, and the placement of surgical drapes. The animals under anesthesia were assisted from the point of view of ventilation with continuous positive airway pressure mask, adapted with rubber tubing to pressure $1,5 \mathrm{kgf} / \mathrm{cm}^{2}$ and positive end-expiratory pressure (PEEP) of $2 \mathrm{~cm} \mathrm{H}_{2} \mathrm{O}$. The weight of the animals was measured by conventional scale before the surgical procedure, and considered the initial weight. After anesthesia, the rats underwent a midline laparotomy incision, starting at the xiphoid process, with a length of $3 \mathrm{~cm}$, followed by detachment of the subcutaneous space and opening of the peritoneal cavity in the linea alba. The right portion of the diaphragm was exposed, followed by the making of a perforating injury with a number 15 scalpel blade. The injury, standardized in 30\% of diaphragmatic surface ${ }^{3}$, initiated at the lateral diaphragmatic edge, in its costal insertion. After this initial incision, we awaited the ipsilateral lung to collapse in order not to cause lung injury. We then progressed with the lesion up until near the tendon center, without including it. The synthesis of the abdominal wall was performed by planes. The aponeurosis was closure with continuous 4.0 poliproprilene and the subcutaneous tissue and the skin with interrupted and inverted 4.0 mononylon. The animals were watched until the end of the anesthetic effect. They were hydrated by subcutaneous injection with $5 \mathrm{ml}$ of $0.9 \%$ saline solution. When wide awake, they were returned to their individual cages.

After the procedure, the rats were kept alive for 21 days. In this period the animals received analgesia and food and water ad Libitum. After 21 days, the animals were weighed. Then they were killed according to international standards for euthanasia of laboratory animals. Next, we performed the autopsy study. After the wide opening of the thoracic and abdominal cavities, we recorded the position of the abdominal organs as were found: whether only in the abdominal cavity or herniated into the chest cavity. We continued to study the diaphragm and observe if it was healed or not, and its relation to the liver.

The sample consisted of 40 animals. Ten animals were kept in collective cages, but were not operated, comprising the control group for weight. Two animals were excluded from the analysis because they died within the 21 postoperative days.
For the nominal qualitative variables we calculated the frequency distribution. The variables regarding healing were: 1) Healing of the diaphragm; and 2) non-healing of the diaphragm (a-hernia; and bdiaphragm injury without hernia). As for the herniated contents of the abdomen into the chest, variables were as follows: colon, small intestine, omentum, stomach, spleen and liver. Variables relating the liver with diaphragmatic healing were: 1) adhered Liver; and 2) Liver not adhered. Variables relating the liver with the non-healing of the diaphragm were: 1) adhered liver; and 2) Liver not adhered.

The continuous quantitative variable "weight" was collected at two time points: preoperatively, initial appointment; and at death, at 21 days. This variable was analyzed descriptively on the reported moments using measures of central tendency ${ }^{4}$. To compare the groups (control, healing and non-healing) in relation to weight, we used analysis of variance (ANOVA), provided that the assumptions of data normality and variance homogeneity were met. These findings were obtained, respectively, by means of the Kolmogorov-Smirnov and Levene ${ }^{5}$ tests. In the case of difference between groups being statistically significant at a confidence level of 5\%, we used the Turkey's test for two by two comparison. If any of the assumptions of ANOVA was not satisfied, we applied the nonparametric Kruskal-Wallis test. And with a statistically significant difference between groups, we used the Mann-Whitney test with Bonferroni correction for paired comparisons ${ }^{6}$. Other statistical tests were used, such as analysis of variance with one factor, analysis of variance with repeated measures, Dunn's test, and nonparametric Kruskal-Wallis test, for studies of significant difference (considered significant $p<0.05$ ).

\section{RESULTS}

Forty rats were included in this study. Ten animals were used as controls for weight and 30 were operated. Two animals died, the operative mortality being $6 \%$. Therefore, we analyzed 38 animals, following the evolution of the diaphragmatic wounds in 28.

There was spontaneous healing of the diaphragm in 15 animals (54\%) (Figure 1), 13 rats (46\%) showing no healing of the diaphragm (Figure 2). Of these, 11 (39\%) had diaphragmatic hernia and two rats had no hernia (7\%).

The average weight at baseline was $221.13 \mathrm{~g}$, with standard deviation (SD) of 13.17. In the postoperative (PO) period (21 days), this average increased to $233.63 \mathrm{~g} \pm$ 33.65. The minimum initial weight was $201 \mathrm{~g}$, and after 21 days, $115 \mathrm{~g}$. The maximum initial weight was $252 \mathrm{~g}$, and at $21 \mathrm{PO}, 276 \mathrm{~g}$. We evaluated these summary measures specific for each evolutionary group (Table 1). There was increase in weights both in the control group and in the healing group. In the non-healing group the average weight decreased. We found that both groups showed no significant 


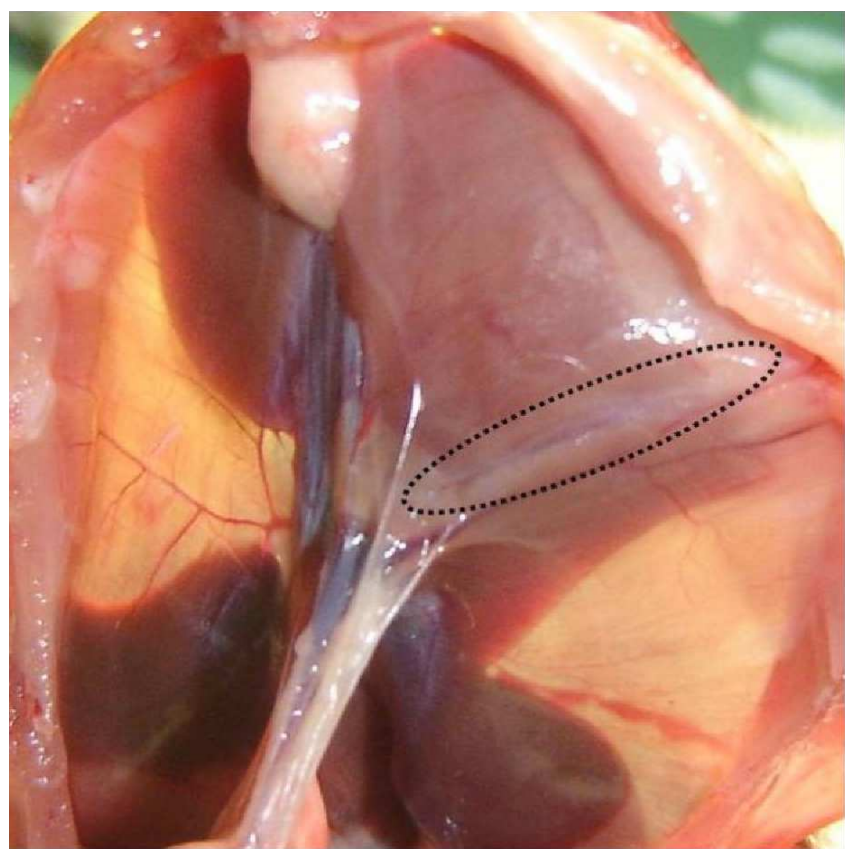

Figure 1 - There is a macroscopic scar on the muscle (surrounded area), a portion with nacreous aspect. There was complete healing.

difference in initial weight $(p=0.952)$. At baseline, the groups were homogeneous with respect to weight. For the evaluation of the groups in relation to weight variation, we calculated the variation percentage [(final weight - initial weight * 100)] (Table 2).

We identified 13 rats that showed no healing of the right diaphragm. In all those animals (100\%) we found the liver with some adhesion to the diaphragm and / or

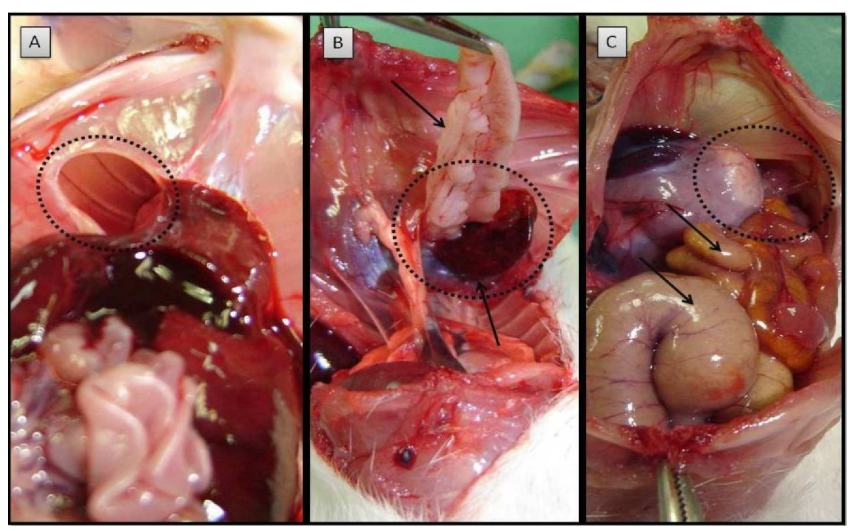

Figure 2 - A) We observe a diaphragmatic injury (circled area). The abdominal viscera are at the foreground and through the lesion the ribs can be seen in the pleural cavity. In this group of animals we did not observe abdominal organs in the pleural cavity. B) In the circled area we note the contents of diaphragmatic hernia formed into the pleural cavity, indicated by the arrows, with the presence of the a liver and omentum segment through the injury. C) The surrounded area shows a diaphragmatic injury, with its well separated edges and through which traverses nearly the entire small and large intestines, indicated by the arrows.

entering the chest cavity. Organ that were also adhered included the: omentum in $77 \%$ of rats; small intestine in $62 \%$; colon in $46 \%$; stomach in $31 \%$; and the spleen in $15 \%$ of animals.

We observed that in all 15 animals with healing of the diaphragm the liver was attached to the muscle. The same situation occurred in 13 animals without diaphragmatic healing. The liver adhered in $100 \%$ of the operated animals.

Table 1 - Measures of weight (grams) at baseline and at 21 days postoperatively according to the group of injury evolution.

\begin{tabular}{lccccccc}
\hline Group & Moment & N & Average & SD & Median & Minimum & Maximum \\
\hline Control & Initial & 10 & 220.00 & 11.67 & 219 & 204 & 243 \\
& 21 days & 10 & 256.20 & 13.61 & 259 & 231 & 276 \\
Healing & Initial & 15 & 221.67 & 15.85 & 219 & 201 & 252 \\
& 21 days & 15 & 241.93 & 22.04 & 250 & 201 & 272 \\
Non-healing & Initial & 13 & 221.38 & 13.19 & 220 & 205 & 246 \\
& 21 days & 13 & 206.69 & 38.60 & 216 & 115 & 250 \\
\hline
\end{tabular}

$N=$ number of animals

$S D=$ standard deviation

Table 2 - Measures the percentage variation in weight (grams), according to the group of injury evolution.

\begin{tabular}{llccccc}
\hline Group & N & Average & SD & Median & Mínimum & Maximum \\
\hline Control & 10 & 16.51 & 4.14 & 15.88 & 11.52 & 23.77 \\
Healing & 15 & 9.22 & 8.25 & 9.83 & -5.12 & 20.09 \\
Non-healing & 13 & -6.26 & 18.62 & -5.12 & -49.56 & 13.88 \\
\hline
\end{tabular}

$N=$ number of animals

$S D=$ standard deviation 


\section{DISCUSSION}

It is common in Emergency rooms the attendance of victims with injury by stabbing or gunshots to the thoracoabdominal transition region. The big question that soon appears to us surgeons is: Is there or is there not a diaphragmatic injury? When these patients are symptomatic, ie, present with peritonitis, hemothorax, eviscerations, presence of diaphragmatic hernia or arrive with hemodynamic instability, the diagnosis is easier, as these patients will receive proper treatment, including exploratory laparotomy. However, $8 \%$ of these patients have no symptoms or are mildly symptomatic. In these situations, especially if the entrance orifice is located in the lower chest, how can one be sure about the presence or not of diaphragmatic injury? It is clear that conducts are different, since the diaphragm ought to be sutured if an injury has occurred, so an operation is mandatory. If there is no diaphragmatic injury, however, treatment may be operative or not. So far there is no imaging study that allows this diagnosis. Most authors on this situation prefer to perform a thoracoscopy or laparoscopy to be sure about the presence or absence of such lesion. And this has been our conduct, although there are studies that claim that there is no chance of spontaneous healing ${ }^{7-9}$. The diaphragm should always be sutured, the diagnosis is imperative.

The laparoscopic surgery, though being a minimally invasive method, is not without complications, so that we begin to question the need for the definitive diagnosis of diaphragmatic injury. Would not the diaphragm have a capacity for spontaneous healing? If this is true, some selected patients would not need to undergo laparoscopic surgery, even if the suspicion of diaphragm injury was great, especially if the injury was to the right and small, such as that produced by a stab wound.

With thi sin mind, we went to the lab to verify if this could be true with animals. In 2001, Perlingeiro et al. conducted the first study. They showed that small injuries of $5 \%$ of the muscle, both on the right and on the left sides, heal spontaneously, occurred in $100 \%$ on the right and $86 \%$ on the left ${ }^{2}$. This was a pioneer work in the international literature and also was the stem of our research.

Gamblin et al. developed a model of diaphragmatic injury and hypothesized that not every injury evolves into a diaphragmatic hernia, with a small penetrating diaphragm injury healing spontaneously ${ }^{10}$. The animals were followed for ten months and $96 \%$ had a healed diaphragm.

Espada analyzed the early evolution of the healing process of the diaphragm muscle after penetrating injury not treated operatively in rats. Diaphragmatic injury was always performed on the left, with $5 \mathrm{~mm}$ length. Animals were studied after euthanasia between 24 hours and seven days, healing being identifying in $20 \%$ of animals ${ }^{11}$. Gonçalves caused $30 \%$ injuries in diaphragms of rats 40 , only on the left, spontaneous healing being found in $7.5 \%$ of animals ${ }^{3}$.

Other authors ${ }^{12,13}$ have used pigs to study the evolution of untreated diaphragmatic injury and also concluded that in these animals the healing of the muscle was possible. Thus, we concluded that at least in laboratory animals, spontaneous healing of a diaphragmatic wound is possible. The liver was always present, adhered to the diaphragm or collaborating with its healing, and the animals in which there was no healing of the diaphragm showed a decrease in weight.

We conclude that there was a predominance of spontaneous healing in the right diaphragm. Animals which had no healing of the diaphragm did not gain weight, and the liver was the organ present in $100 \%$ of the diaphragmatic surface of rats, be it healed or not.

Can we then treat a patient victim of a thoracoabdominal injury, who is asymptomatic, without surgery, believing that healing will occur spontaneous? We still do not have this answer ${ }^{14}$, although some authors believe that it is possible ${ }^{15,16}$.

\section{R E S U M O}

\footnotetext{
Objetivo: avaliar a cicatrização natural do diafragma de ratos que sofreram um ferimento penetrante extenso à direita. Métodos: os animais sofreram uma lesão penetrante extensa no diafragma direito. A amostra foi composta por 40 animais. As variáveis estudadas foram peso inicial e em 21 dias de operados; cicatrização do diafragma, não cicatrização do diafragma e conteúdo herniado do abdome para o tórax. Resultados: dez animais constituíram o grupo controle para o peso e 30 animais foram operados. Dois animais morreram durante o experimento, sendo assim, 28 animais constituíram o grupo de operados; ocorreu a cicatrização do diafragma em 15 animais (54\%), outros 11 animais apresentaram hérnia diafragmática (39\%) e por fim em dois animais observamos somente lesão diafragmática sem hérnia (7\%). Analisando os órgãos herniados, encontramos o fígado em 100\% dos animais, seguido pelo omento em 77\%; delgado em 62\%; cólon em 46\%; estômago em $31 \%$ e baço em $15 \%$. Os grupos controle e de cicatrização do diafragma apresentaram acréscimo significativo de peso do momento inicial para o momento 21 dias $(p<0,001)$. O grupo não cicatrizado não apresentou alteração de peso $(p=0,228)$. Conclusão: há predomínio da cicatrização espontânea no diafragma à direita, os animais em que não houve a cicatrização do diafragma não aumentaram de peso, e o fígado foi o órgão $100 \%$ presente na superfície diafragmática em todos os ratos com cicatrização ou não do diafragma.
}

Descritores: Diafragma. Cicatrização de Feridas. Diafragma/lesões. Experimentação Animal. 


\section{REFERENCES}

1. Marchant P. A study of the forces productive of gastro-esophageal regurgitation and herniation through the diaphragmatic hiatus. Thorax 1957;12(3):189-202.

2. Perlingeiro JA, Saad R Jr, Lancelotti CL, Rasslan S, Candelária PC, Soldá SC. Natural course of penetrating diaphragmatic injury: an experimental study in rats. Int Surg. 2007;92(1):1-9.

3. Gonçalves R. Análise da evolução natural das feridas perfurocortantes equivalente a $30 \%$ do diafragma esquerdo. Estudo experimental em ratos [dissertação]. São Paulo: Faculdade de Ciências Médicas da Santa Casa de São Paulo; 2008.

4. Massad E, Menezes RX, Silveira SPP, Ortega NRS. Métodos quantitativos em Medicina. São Paulo: Manole; 2004.

5. Neter J, Kutner M, Wasserman W, Nachtsheim CJ. Applied Linear Statistical Models. 40 th ed. New York: McGraw-Hill; 1990.

6. Noether GE, Dueker M. Introduction to Statistics: The Nonparametric Way. Springer Texts in Statistics. New York: Springer; 1990

7. Shackleton KL, Steward ET, Taylor AJ. Traumatic diaphragmatic injuries: spectrum of radiographic findings. Radiographics.1998;18(1):49-59.

8. Dorgan Neto V, Saad Júnior R, Rasslan S. Videotoracoscopia no trauma de tórax. Rev Col Bras Cir. 2001:28(1):3-8.

9. Soldá SC, Rodrigues FCM, Martins L, Pinto MCC, Raslan S. Lesão diafragmática isolada por ferimento penetrante tratada por videolaparoscopia. Rev Col Bra Cir. 1994;21(4):213-5.

10. Gamblin TC, Wall CE Jr, Morgan JH 3rd, Erickson DJ, Dalton ML, Ashley DW. The natural history of untreated penetrating diaphragm injury: an animal model. J Trauma. 2004;57(5):989-92.
11. Espada PC. Ferimento diafragmático: evolução do processo cicatricial e regeneração muscular [dissertação]. Ribeirão Preto, SP: Faculdade de Medicina de Ribeirão Preto/USP; 2006.

12. Zierold D, Perlstein J, Weidman ER, Weidman JE. Penetrating trauma to the diaphragm: natural history and ultrasonographic characteristics of untreated injury in a pig model. Arch Surg. 2001;136(1):32-7.

13. Shatney $\mathrm{CH}$, Sensaki K, Morgan L. The natural history of stab wounds of the diaphragm: implications for a new management scheme for patients with penetrating thoracoabdominal trauma. Am Surg. 2003;69(6):508-13.

14. Saad Jr R. E o Diafragma? Rev Col Bras Cir. 2012;39(5):351.

15. De Rezende Neto JB, Guimarães TN, Madureira JL Jr, Drumond DA, Leal JC, Rocha Jr A, et al. Non-operative management of right side thoracoabdominal penetrating injuries - the value of testing chest tube effluent for bile. Injury. 2009;40(5):506-10.

16. Inaba K, Barmparas G, Foster A, Talving P, David JS, Green D, et al. Selective nonoperative managemant of torso gunshot wounds: when is it safe to discherge? J Trauma. 2010;68(6):1301-4.

Received on 30/05/2013

Accepted for publication 02/10/2013

Conflict of interest: none.

Source of funding: Fund for Research Support of the Faculdade de Ciências Médicas da Santa Casa de São Paulo (FCMSC-SP).

\section{Mailing address:}

José Gustavo Parreira

E-mail: jgparreira@uol.com.br 